\title{
The Right of Individuals to Take Judicial Action Against International Persons: The Case of NATO's Intervention in Libya
}

\author{
Mohamad Ghazi Janaby $y^{\text {K }}$ \\ Khaled Ramadan Bashivi
}

\begin{abstract}
Keywords
Libya, NATO intervention, responsibility of international organisations, individual criminal responsibility, universal jurisdiction, diplomatic protection, state responsibility, international criminal court, complementarity, war crimes, crimes against humanity, human rights law
\end{abstract}

\section{Introduction}

Traditionally, individuals could bring their claims to international court(s) against international persons through their states representing them before courts by way of 'diplomatic protection'. What then are the legal solutions if the state is unable or unwilling to pursue the case on behalf of the individual? Where can an individual seek justice if an international person caused the damage?

This article focuses on the right of individuals to make claims against international persons. Crimes allegedly committed by NATO and other states forces' during the war in Libya will be taken as a practical example for this study. The article will analyse the right of Libyan victims harmed by these actors' bombardment to take legal action within or outside Libya; whether such action be civil, criminal or both.

PhD Candidate, School of Law, University of Aberdeen, LLM in Public International Law from University of Babylon, Iraq, tutor at College of Law, University of Babylon, Iraq).

$+\mathrm{PhD}$ in Law from University of Aberdeen, Libyan Public Prosecutor, currently Teaching Fellow of Arabic at University of Aberdeen. LLM in International Law and World Order from the University of Reading (2006). 


\section{The Libyan Case}

NATO and other state forces operating under its command during the 2011 war in Libya have been accused of the killing of civilians and the destruction of civilian property, schools, hospitals and places of worship. According to several reports received by the UN Commission of Inquiry, in the first four months alone NATO's strikes against civilian targets have:

resulted in the death of 500 civilians and 2,000 injured. The same reports stated that NATO had targeted schools, universities, mosques, and others civilian locations. According to the same sources, 56 schools and three universities were directly hit by these strikes. Furthermore, it is claimed that NATO airstrikes have resulted in the closure of 3204 schools, leaving 437, 787 students without access to education 2

For example, in the village of Majer, NATO's bombardment killed 85 civilians including 32 women and 33 children ${ }^{3}$ Also, in a single day in September it was claimed that "NATO air strikes ... killed a total of 354 people in the loyalist stronghold of Sirte" ${ }^{4}$ NATO did not investigate these claims but made some general statements that everything was done with the intent to avoid civilian casualties. This prompted a Senior Crisis Adviser at Amnesty International, Donatella Rovera to state that "they cannot now brush aside the deaths of scores of civilians with some vague statement of regret without properly investigating these deadly incidents"

1 By 31 May these states were: Belgium, Bulgaria, Canada, Denmark, France, Greece, Italy, Jordan, Netherlands, Norway, Qatar, Romania, Spain, Sweden, Turkey, UAE, UK and USA. See Report of the International Commission of Inquiry to Investigate All Alleged Violations of International Human Rights Law in the Libyan Arab Jamahiriya, UN Doc. A/HRC/17/44 (2011), at 29.

2 Ibid., at 77.

3 M. Ryan, 'Tripoli Says NATO Strike Kills Dozens of Civilians', Reuters, 09 August 2011, <http://www.reuters.com/article/2011/08/09/us-libya-idUSTRE76Q76620110809> [last accessed 26 March 2012].

4 K. Sengupta, 'NATO Strikes "Kill 354", Says Gaddafi's Spokesman', The Independent, 18 September 2011, <http://www.independent.co.uk/news/world/africa/nato-strikes-kill354-says-gaddafis-spokesman-2356574.html> [last accessed 26 March 2012].

5 M. Holden, 'NATO Failed to Probe Libya Civilian Deaths-Amnesty', Reuters, 19 March 2012, <http://uk.reuters.com/article/2012/03/19/uk-libya-amnesty-nato-idUKBRE82I04X20120 319> [last accessed 29 July 2012]. 
Acts allegedly amounting to war crimes and crimes against humanity committed during this war by government forces on the one hand and rebel forces, NATO and its allies on the other, arguably may have exceeded collateral damage or simple acceptable miscalculations ${ }^{6}$ Assuming such atrocities have taken place, victims of alleged atrocities ought to have access to justice to seek punishment of criminals and compensation for losses and damage suffered.

\section{International Responsibility of International Organisations}

The International Law Commission's (ILC) Draft Articles on the Responsibility of International Organizations (DARIO) states that responsibility can be held jointly and singly between the organisation and member states:7 Article 7 stipulates that "the conduct of an organ of a State ... that is placed at the disposal of another international organization shall be considered under international law an act of the latter organization if the organization exercises effective control over that conduct" 8

The main condition for this responsibility is that the receiving organisation has effective control over the seconded organ. If the contributing states retain disciplinary powers and criminal jurisdiction over their national troops, the state would still be responsible?

In Al-Jedda $v$ United Kingdom the European Court of Human Rights (ECtHR) concluded that "the United Nations Security Council [(SC)] had neither effective control nor ultimate authority and control over the acts and omissions of troops within the Multi-National Force and that the applicant's detention was not, therefore, attributable to the United Nations" ${ }^{10}$ but the internment of the applicant was attributable to the United Kingdom as it was British troops that had committed the wrongful act in Iraq ${ }^{11}$

6 See Amnesty International, 'Libya: The Forgotten Victims of NATO Strikes,' 19 March 2012, MDE 19/003/201, <http://www.unhcr.org/refworld/docid/4f68451e2.html> [last accessed 26 September 2012].

7 ILC DARIO, 2011/2 (II) ILC Ybk, at 54. See also K. E. Boon, 'New Directions in Responsibility: Assessing the International Law Commission's Draft Articles on the Responsibility of International Organisations', (Spring 2011) 37 YJIL Online 1, at 2.

8 ILC DARIO, Art. 7, supra note 7, at 55.

9 Ibid., at 87.

10 Al-Jedda $v$ The United Kingdom, Judgement of 7 July 2011, [2011] ECtHR (Ser 1092), para. 84.

11 Ibid., para. 86. 
Attribution of an internationally wrongful act to both the member states and NATO amounts to 'joint and single' responsibility ${ }^{12}$ This dual attribution is because authority and control over the military forces is shared between a state and the organisation. Moreover, in the case of the Legality of the Use of Force before the International Court of Justice (ICJ), Brownlie advanced the view that "the North Council directs the war against Yugoslavia as a joint enterprise' ${ }^{13}$ which suggests that NATO is a military alliance acting through its member states $[14$

In this regard, NATO itself admitted this view in its comments sent to the ILC. It believes that each member state "retains full responsibility for its decision" as all NATO's decisions are taken by consensus after a full discussion and consultation among representatives of member states and these decisions reflect "the collective will of the sovereign member states"

Accordingly, NATO, its member-states and other states operating under its command are responsible jointly and singly for any wrongful acts they allegedly committed in Libya during Operation Unified Protector. Although this operation was carried out pursuant to SC Resolution 1973, the SC is not responsible for those acts, as it did not have effective control and command over the armed forces ${ }^{16}$

In relation to the responsibility of international organisations towards individuals, Article 33 (2) of the DARIO states that the right of individuals to reparation should not be affected by establishing the international responsibility of international organizations ${ }^{17}$ This leads to the conclusion that individuals harmed by the wrongful acts of NATO, its member-states and states operating under its command have the right to make claims against NATO, any of its member states and states operating under its command 'jointly and singly'.

12 Boon, supra note 7 , at 2.

13 Legality of the Use of Force (Serbia and Montenegro $v$ Netherlands), Public Sitting, Verbatim Record, CR99/25, 1999, at 16 <http://www.icj-cij.org/docket/files/109/4597.pdf> [last accessed 11 November 2012].

14 B. Boutin, 'What Responsibility for States Participating to a Lesser Extent to The NATO Operation in Libya' <http://www.sharesproject.nl/what-responsibility-for-statesparticipating-to-a-lesser-extent-to-the-nato-operation-in-libya/> [last accessed 02 April 2012].

15 ILC, Responsibility of International Organizations Comments and Observations Received from International Organizations, 2011/36, U.N. Doc. A/CN.4/637 (2011), at 12.

16 Boon, supra note 7, at 2.

17 Art. 33 (2) of DARIO stipulates: "This Part is without prejudice to any right, arising from the international responsibility of an international organization, which may accrue directly to any person or entity other than a State or an international organization", supra note 7, at 61. 


\section{The Responsibility of States Towards Individuals}

International Humanitarian Law (IHL) provides for the right of individuals to be compensated by states in respect of armed conflict based on Article (3) of the Hague Convention on Land Warfare 190 $7^{18}$ and Article 91 of the Additional Protocol I 1977 (API) to the Geneva Conventions 1949 ${ }^{19}$ In essence, the parties to a conflict, regardless of whether they are victor or vanquished are bound to compensate individuals damaged by a wrongful act committed by the members of their armed forces in violation of IHL.

The ICJ accepted that states could compensate individuals directly when it highlighted Israel's obligation to provide restitution or compensation to individual Palestinians directly for damages resulting from constructing the Wall in the occupied territories ${ }^{20}$ This advisory opinion asserted that damages to individuals caused by unlawful acts of states must be compensated through the direct relationship between states and individuals, especially as those damages occurred due to violations of IHL and international human rights law.

Article 33 (2) of the ILC Articles on Responsibility of States for Internationally Wrongful Acts (ARSIWA) adopted in 2001 stipulates that "this Part is without prejudice to any right, arising from the international responsibility of a state, which may accrue directly to any person or entity other than a state" ${ }^{21}$ This represents a clear declaration of the right of individuals or entities to invoke the responsibility of states that violate primary norms of international law on their own account 22

The right of individuals to reparation is also asserted by the commissions of compensation sometimes instituted after the end of armed conflicts. In this vein, there were two important commissions providing compensation to people who suffered from breaches of IHL. The first one was the United Nations Compensation Commission (UNCC), established by the SC in 1991 to compensate victims of the Iraqi invasion of Kuwait ${ }^{23}$ The Commission dealt with claims of individuals, corporations and governments, and it received more

181907 Hague Convention (IV) on the Laws and Customs of War on Land. Art. 3.

191977 Additional Protocol I to the Geneva Conventions, 1125 UNTS 3, Art. 91.

${ }^{20}$ Legal Consequences of the Construction of a Wall in the Occupied Palestinian Territory, Advisory Opinion, ICJ Reports 2004, p. 136, at 198, para. 153.

21 ILC Articles on Responsibility of States for Internationally Wrongful Acts, with commentaries, 2001/2(II) ILC Ybk, at 94.

22 Ibid., at 95.

23 SC Res 687, 3 April 1991. 
than 2.6 million claims asking for compensation with around $\$ 352$ billion ${ }^{24} \operatorname{In}$ essence, the SC has adopted the principle that the liability could be from states to individuals and not just interstate ${ }^{25}$ the majority of these 2.6 million claims were submitted by individuals. ${ }^{26}$

The second commission is the Eritrea-Ethiopia Claims Commission (EECC) established in 2000 according to the Eritrea-Ethiopia Peace Agreement. The main function of this commission was to compensate entities, including individuals, for damages resulting "from violations of international humanitarian law, including the 1949 Geneva Conventions or other violations of international law"

The conclusion from the foregoing is that states have direct international responsibility towards the individual, regardless of the method of implementing this responsibility.

On the other hand, it has been proposed that criminal responsibility can be extended to include states ${ }^{28}$ However, there has been a heated debate on this issue and it seems that the concept of criminal responsibility applied in domestic law cannot be applied to states at the international level ${ }^{29}$ For this reason, some refuse to adopt the criminal responsibility of the state in international law on the grounds that the state is merely a fictional entity and only individuals can commit crimes ${ }^{30}$ Therefore, there is a lack of rules that support the criminal responsibility of the state itself and this responsibility should be directed to the representatives of states. The clearest example of this is the Nuremberg and Tokyo trials that were carried out against the German and Japanese commanders rather that against Germany and Japan. This article concludes that international law today does not provide impunity for officials of international organisations while allowing prosecution of state officials.

24 'The Claims' <http://www.uncc.ch/theclaims.htm> [last accessed 09 March 2012].

25 L. Zegveld, 'Remedies for Victims of Violations of International Humanitarian Law', (2003) 85 IRRC 497, at 521.

26 'The Claims', supra note 24.

272000 Agreement between the Government of the State of Eritrea and the Government of the Federal Democratic Republic of Ethiopia, 2138 UNTS 94, Art. 5

28 See C. Gilbert, 'The Criminal Responsibility of States', (1990) 39 ICLQ 345, at 366.

${ }^{29}$ Judge Krylov accepted the use of terms, normally used in domestic law, in international law by stating that "the terms of Roman law and of contemporary civil and criminal law may be used in international law, but with certain flexibility and without making too subtle distinctions. There is no need to transfer the distinctions which we sometimes meet in certain systems of municipal law into the system of international law." Corfu Channel Case (United Kingdom v Albania), Merits, Judgement, ICJ Reports 1949. p. 4, at 71 (Judge Krylov Dissenting Opinion).

30 See C. Gilbert, supra note 28, at 366. 
With this in mind, the next section will discuss the possible avenues for individuals to take judicial action against international persons with special reference to the Libyan case.

\section{International Instruments Providing Individuals with the Right to Complain Against International Persons}

In the twenty-first century, the ability of individuals to bring cases directly before international courts and tribunals should not be an imaginary notion. In fact, individual victims were able to make claims against Germany before the Mixed Arbitral Tribunal according to the 1919 Treaty of Versailles ${ }^{31}$ Furthermore, individuals were enabled by the Treaty of 1907, between five Central American states, to bring cases directly before the Central American Court of Justice ${ }^{32}$ Under the Hague Convention of 1907 individuals were also provided with the right to directly appeal to the International Prize Court 33 Similarly the tribunal created under the Upper Silesia Convention in 1922 decided that it was competent to hear cases by the nationals of a state against that state ${ }^{34}$ What then are the current options for individuals to make claims against international persons?

\subsection{Diplomatic protection (indirect instruments)}

The first avenue individuals would traditionally pursue in order to seek justice against an international person is through their own state. In this case, the state would initiate a legal action against an international person on behalf of its citizen(s). Relatedly, when NATO faced allegations of war crimes and crimes against humanity in November 2011, it claimed that it was the Libyan interim authorities who should be responsible for initiating any inquiry into these allegations. However, the Libyan authorities, whose ascent to power was

\footnotetext{
311919 the Peace Treaty of Versailles, signed on 28 June 1919, Art. 304 (b).

32 M.M. Whiteman, Digest of International Law (United States Government Printing Office, 1963-73), Vol I, at 39.

331907 Hague Convention (XII) relative to the Creation of an International Prize Court, Art. 4(3) (never entered into force), available at <http://www.icrc.org/ihl.nsf/FULL/235?Open Document $>$ [last accessed 14 Nov 2012]

${ }^{34}$ See Steiner and Gross v Polish State (1928) 4 ILR 291
} 
made possible by the help of NATO's airstrikes, are reluctant to take any action in this respect ${ }^{35}$

As the aim of this article is to discuss the avenues available for individual victims to directly raise their claims before international fora, discussing diplomatic protection is only relevant as far as to assert that a state's lack of interest or inability to initiate diplomatic protection does not hinder individuals from directly taking action.

In Barcelona Traction, the ICJ held that a state had discretion as to whether or not to take action on behalf of its injured citizen and to determine to what extent reparation should be paid ${ }^{36}$ Nevertheless, this 1970s ICJ decision has been challenged by many recent developments affecting the course of international law. Today, individuals have the right to seek justice in alternative avenues ${ }^{37}$ Furthermore, Gaja commenting on the ILC Articles on Diplomatic Protection 38 concluded that "it is not to be assumed that the ability of an individual to exercise his/her rights is affected by the fact that international law provides a state with a remedy with regard to the individual's injury.' 39 He referred to Article 16 which stressed that the right of "natural persons, legal persons or other entities to resort under international law to actions or procedures other than diplomatic protection to secure redress for injury suffered as a result of an internationally wrongful act, are not affected by the present draft articles.' 40

Therefore, in the likely event where the Libyan State is unwilling (or unable) to provide diplomatic protection to bring cases of redress against NATO and its allies, the right of individuals to resort to remedies other than diplomatic protection will not be affected.

35 C. J. Chivers and E. Schmitt, 'In Strikes on Libya by NATO, an Unspoken Civilian Toll', New York Times, 17 Nov 2011, <http://www.nytimes.com/2011/12/18/world/africa/scoresof-unintended-casualties-in-nato-war-in-libya.html?_r=1> [last accessed 29 July 2012]

36 The Barcelona Traction, Light and Power Company, Limited, (Belgium v Spain), Second Phase, Judgment of 5 February 1970, ICJ Reports (1970), p. 3, at 45, para 78-9.

37 R. McCorquodale, 'The Individual and the International Legal System' in M. D. Evans (ed), International Law (Oxford University Press, 2010), 293-4.

38 Articles on Diplomatic Protection, ILC Report of the Fifty-Eighth Session, UN Doc. A/61/10 (2006), at 16.

39 G. Gaja, 'The Position of Individuals in International Law: An ILC Perspective', (2010) 21(1) EJIL 11, at 13 .

40 Articles on Diplomatic Protection, supra note 38, at 86. 


\subsection{The right to complain under international human rights law}

Under international human rights law there are two main avenues according to which individuals have the right to directly bring cases against international persons accused of committing wrongful acts. Traditionally this was done through commissions or quasi-judicial bodies. Nowadays, however, proper and effective courts are taking the lead in allowing individuals direct access to justice against international persons.

\subsubsection{Quasi-judicial bodies}

Human rights treaty bodies may consider individual complaints or communications from individuals. The competence of these committees to consider complaints from individuals is based on the acceptance by states parties of their jurisdiction to receive petitions from individuals. This is subject to the condition of prior exhaustion of all domestic remedial measures ${ }^{41}$

Moreover, regionally, human rights conventions have been quite regular with the practice of endowing individuals with the right to similar remedies against states. For example, in 1969 Articles 44 and 45 of the American Convention of Human Rights gave the Inter-American Commission "compulsory jurisdiction for individual complaints and optional jurisdiction for inter-state complaints". This is the opposite of the case of the European Commission on Human Rights, which was given optional jurisdiction over individual petitions and compulsory jurisdiction with regard to inter-state complaints. ${ }^{42}$

Although these committees are not judicial entities, they are described as quasi-judicial mechanisms as they have the ability to assess whether a concerned state is in breach of its treaty obligations. Accordingly, they have a variety of competences to remedy issues raised before them such as compensating the victims ${ }^{43}$ abolishing the violating legislation and releasing

41 'Human Rights Treaty Bodies - Individual Communications' <http://www2.ohchr.org/en glish/bodies/petitions/individual.htm> [last access 05 February 2012]'

42 See K. Parlett, The Individual in the International Legal System Continuity and Change in International Law (Cambridge University Press, 2011), 329.

${ }^{43}$ For example, in the cases Sattorov, 1200/2003 and Idiev, 1276/2004 v Tajikistan the Human Rights Committee recommended an effective remedy, including initiation and pursuit of criminal proceedings to establish responsibility for the ill-treatment of the author's son and a payment of adequate compensation. General Assembly, Report of the Human Rights Committee, UN Doc. A/65/40 Vol. I (2010), at 156. 
prisoners ${ }^{44}$

\subsubsection{Human rights courts}

In the field of human rights, the practice of endowing direct rights on individuals and enabling them to have direct accesses to justice before international courts and tribunals is all too common. For example, the African Court on Human and People's Rights has optional jurisdiction over complaints directly submitted by individuals ${ }^{45}$ In addition, the ECtHR "has competence to receive applications directly from individuals" ${ }^{46}$ Furthermore, the jurisdiction of the ECOWAS ${ }^{47}$ Community Court of Justice (ECCJ) was modified in 2005 and has admitted "the legal possibility for individuals to access the ECCJ to seek relief for violations of their human rights. ${ }^{48}$

Individuals whose rights, particularly one of their fundamental human rights such as the right to life, have been affected by an internationally wrongful act should be able to make direct claims before these bodies. This, however, must be done in accordance with the jurisdictional and procedural requirements. Thus, for example, all local remedies must be exhausted and the act must fall under the jurisdiction of the human rights court approached. This is because these courts might not have universal jurisdiction, as many would think. For example, in Banković and Others v Belgium, the ECtHR held the case inadmissible as it did not fall within the territorial jurisdiction of the respondent states ${ }^{49}$

Thus, in the case of Libya, the African Court on Human and People's Rights should be the normal place of resort. The right of individuals to have direct access to this court is based on their states' acceptance of its jurisdiction ${ }^{50}$

44 A. Kjærum, 'The Treaty Body Complaint System, A survey of recent decisions by treaty bodies on individual complaints', (2010) 3 Human Rights Monitor Quarterly $<$ http://www.ishr.ch/quarterly> [last accessed 14 November 2012]. See also A. F. Bayefsky, The UN Human Rights Treaty System University at the Crossroads (Kluwer Law International, 2001), at 32.

45 Parlett, supra note 42, 331.

46 Ibid., 331-33.

47 Economic Community of West African States.

48 S. T. Ebobrah, 'Critical Issues in the Human Rights Mandate of the ECOWAS Court of Justice', (2010) 54 (1) Journal of African Law 1, at 1-2.

49 Banković and Others $v$ Belgium and 16 Other Contracting States, Admissibility Decision of 12 December 2001, [2001] ECtHR 435, para 80.

501998 Protocol to the African Charter on Human and Peoples' Rights on the Establishment of an African Court on Human and Peoples' Rights, adopted by the Organization of African Unity (OAU) in Burkina Faso, Arts. 5 (3); 34 (6). Libya ratified this protocol on 
Although the court has jurisdiction over Libya, as of April 2012 Libya still has not made the required declaration, which would allow individuals to directly access the court ${ }^{51}$ Thus, Libyan individuals cannot access this court directly until Libya declares its acceptance of such jurisdiction. But even if Libya made this declaration, Libyan victims would only be able to bring claims against the Libyan government.

\subsection{Domestic courts}

\subsubsection{Domestic courts with territorial jurisdiction}

The domestic courts in the territory where the crime or the damage occurred are normally where justice should be sought. This jurisdiction can cover both criminal and civil cases. "Indeed, legislation encompassing exterritorial conduct is the exception, rather than the norm to the prosecutorial practice and preference of States. ${ }^{52}$ In its Preamble, the International Criminal Court (ICC) Statute emphasises that "the International Criminal Court established under this Statute shall be complementary to national criminal jurisdictions". The ICC Statute requires exhaustion of all local remedies before any case can be admitted by the court. Thus, the primary avenue for trials of crimes (including international crimes) should be domestic courts. Domestic courts would normally be able to offer justice with regard to all types of crimes and order damages.

Article 17 of the Rome Statute mentions two cases where the domestic jurisdiction is considered unable or unwilling to offer justice to victims and try criminals. In those cases, the availability of domestic courts would not be an obstacle for victims to take their plea for justice elsewhere. Therefore, if the state is unable or unwilling to investigate the crimes, the rule of complementarity will allow the ICC to take action when possible, subject to the principle of double jeopardy 53

An injured Libyan should naturally look at Libyan courts as his/her first option. However, the Libyan case shows that the state is not taking any action towards investigating alleged wrongdoings of NATO and other states

19 November 2003. See <http://www.africa-union.org/root/au/Documents/Treaties/Li st/Protocol\%20on\%20the\%20African\%20Court\%20on\%20Human\%20and\%20Peoples\%20 Rights.pdf $>$ [last accessed 31 October 2012].

51 African Court on Human and Peoples' Rights, 'African Court in Brief' <http://www.africancourt.org/en/index.php/about-the-court/brief-history> [last accessed 1 October 2012]

52 I. Bantekas, International Criminal Law (Hart Publishing, 2010), 332.

531998 Rome Statute of the International Criminal Court, 2187 UNTS 90, Arts. 17 and 20. 
in Libya ${ }^{54}$ In fact, the Libyan government has not supported any claims that either NATO or its allies committed wrongful acts in Libya 55

There is no clear-cut objective basis to evaluate the willingness of a state 56 "A state is 'unable' when chiefly on account of total or partial collapse of its judicial system, it is not in a position: (i) to detain the accused or to have him surrendered by the authorities or bodies that hold him in custody; or (ii) to collect the necessary evidence; or to carry out criminal proceedings. 57 In Libya today there is no effective army, nor effective policing or an effective government. The judiciary has been inoperative for more than a year with no sign of improvement ${ }^{58}$ The Libyan state is therefore unable to investigate these crimes now or in the near future. Thus, as McCarthy puts it "despite the attractions of coherent national remedial responses to patterns of mass victimization, often national processes are non-existent, dysfunctional or in ruin, as is presently the case in Libya." 59 Moreover, paragraph 6 of Security Council (SC) resolution 1970 confers immunity upon non-Libyans acting according to the SC's authorised or commissioned operations against prosecution in all jurisdictions but that of the national state of the alleged perpetrator of the wrongdoing. This immunity, however, does not apply to nationals of ICC member states, as they were not included within the ambit of this exclusion clause in SC resolution 1970. Therefore, this immunity is inapplicable against non-Libyans whose states are party to the ICC statute, who

54 See Amnesty International, supra note 6.

55 See for example the case reported by ABC News where the head of the Libyan rebels' government was more keen on dismissing claims against NATO than NATO itself: M. Marquez, L. Martinez and D. Schabner, 'Libyan Rebels Doubt Government Claims Gadhafi Son Was Killed', ABCNews, 1 March 2011, <http://abcnews.go.com/International/libyan-rebelsdismiss-government-claims-moammar-gadhafi-son/story?id=13503526> [last accessed 14 March 2012].

56 S. Hassanein, The Principle of Complementarity Between International and National Criminal Courts, (Unpublished PhD Thesis: University of Aberdeen, 2010), 156-67. See also M. Benzing, "The Complementarity Regime of the International Criminal Court: International Criminal Justice between State Sovereignty and the Fight against Impunity' (2003) in MPEPIL (online edition) Vol 7, at 605.

57 A. Cassese, International Criminal Law (Oxford University Press, 2008), 343-4.

58 In an interview with Libya Al-Hurra TV, on 29th March 2012, a member of the Libyan National Transitional Council (NTC) (Mr Albaajah) has confirmed there is no possibility of fair trials taking place in Libya. He has confirmed that there is no effective government, no effective police and no effective army. He has also confirmed that the justice system is inoperative. Alminbar, Libya Al-Hurra TV, 10am 29th March 2012.

59 C. McCarthy, 'What Happens to the Frozen Fortune? The Libya Situation and Claims for Reparation', (2011) 3 EHRLR 318, at 322. 
are accused of wrongdoing.

\subsubsection{Domestic courts with personal (nationality) jurisdiction}

Some states apply the principle of personal or nationality-based jurisdiction under which their nationals could be tried for crimes even if they were committed elsewhere and have no other connection to the state of nationality. Even in states where the territoriality principle is dominant, some practices of the personal jurisdiction principle can still exist in relation to some crimes. For example, although in the UK the territoriality principle is prevalent, some crimes can still be prosecuted under the nationality jurisdiction principle

Nationality-based jurisdiction, in some cases, is extremely useful to counter impunity. This is especially true when the state with the territorial jurisdiction over the crime is unable to detain or prosecute the criminal. For example, if a state has received another's army to operate on its territory under the condition that none of the sending state's personnel is to be tried for crimes committed while on duty ${ }^{6}$ In such a case, the state on whose territory the crime is committed is handicapped. The sending state must apply the personal jurisdiction principle to prosecute its personnel to avoid impunity. UN peacekeeping missions have applied this principle when any UN personnel commit a crime while on duty 62

If a state exercising personal jurisdiction tries the alleged criminal (its national), this will prevent the ICC from prosecuting him/her according to Article 18(1) 63

However, the SC has reinforced this jurisdiction with regard to nationals of states not parties to the Rome Statue. In its referral of the Libyan case to the ICC, the SC asserted that:

nationals, current or former officials or personnel from a State outside the Libyan Arab Jamahiriya which is not a party to the Rome Statute of the International Criminal Court shall be subject to the exclusive jurisdiction of that State for all alleged acts or omissions arising out of or related to operations in the Libyan Arab

\footnotetext{
$\overline{60}$ See Bantekas, supra note 52, at 338-9.

61 Ibid., at 350-2.

62 "As a matter of internal organisation, with respect to UN and other multinational forces, jurisdiction over offences committed in the context of such operations remains with the State of the nationality of the accused." Ibid., at 351.

${ }^{63}$ A. Cassese, supra note 57, at 344.
} 
Jamahiriya established or authorized by the Council, unless such exclusive jurisdiction has been expressly waived by the State ${ }^{64}$

With regards to non-parties to the Rome Statute (such as the USA), that participated in the Libyan war, their citizens can only be prosecuted for wrongful acts committed during these operations in their own domestic courts, according to the principles of nationality jurisdiction and according to the SC referral.

Personal jurisdiction does not only apply to criminal cases but it also applies to civil matters. In this context, there are a number of cases raised by Libyan victims before the Belgian civil courts against NATO based on this jurisdiction, as the latter's headquarters is in Brussels. The French international lawyer Marcel Ceccaldi, acting on behalf of some Libyan victims, explained "that although international organizations such as NATO enjoy diplomatic immunity in criminal cases, they fall under the jurisdiction of Belgian justice in civil suits.' ${ }^{65}$ In fact, according to media reports, a Belgian court is currently looking into a case brought by some Libyan victims against NATO ${ }^{66}$ Thus, the court has set a precedent that not only states can be sued by individuals for damages but also international organisations.

\subsubsection{Domestic courts with universal jurisdiction}

The Report of the Technical Ad hoc Expert Group on the Principle of Universal Jurisdiction defines universal jurisdiction as "the assertion by one state of its jurisdiction over crimes allegedly committed in the territory of another state by nationals of another state against nationals of another state where the crime alleged poses no direct threat to the vital interests of the state asserting jurisdiction.: 67

${ }^{64}$ SC Res 1973, 26 February 2011, para 6.

65 S. Lekic, 'Libya Lawsuit: NATO Sued Over Bombing Campaign', Huffington Post, 28 July 2011, <http://www.huffingtonpost.com/2011/07/28/libya-lawsuit-nato_n_912033.html> [last accessed 29 July 2012]

${ }^{66}$ International Coalition to Ensure NATO Accountability, 'Libyan national and a Moroccan national, lift diplomatic immunity from NATO' (2012) <http://icena.org/news.html $>$ [last accessed 29 July 2012]. See also K. Skalli 'Le procès intenté par Abdellatif Chlih contre l'Otan, pour l'assassinat de sa fille Aïcha, débute le 23 août prochain devant le tribunal de première instance de Bruxelles' (2012) <http://www.ghislainduboisavocat.be/medias-bruxellesprotege-l-otan.php $>$ [last accessed 2 December 2012]

${ }^{67}$ AU-EU Expert Report on the Principle of Universal Jurisdiction, <http://ec.europa.eu/dev elopment/icenter/repository/troika_ua_ue_rapport_competence_universelle_EN.pdf > [last accessed 3 August 2012], at 7. 
This principle has been accepted and exercised by many states largely over international crimes. Moreover, different treaties require states parties to authorise their criminal justice systems to exercise universal jurisdiction over certain crimes, such as the Convention for the Protection of All Persons from Enforced Disappearance ${ }^{68}$ and the Convention against Torture (CAT) ${ }^{69}$ In this regard, in the question relating to the Obligation to Prosecute or Extradite (Belgium v Senegal), the ICJ emphasised the obligations established by international conventions (specifically the CAT and the 1970 Convention for the Suppression of the Unlawful Seizure of Aircraft) for states to exercise their universal jurisdiction in order to prosecute the crimes stipulated in these conventions, even if these crimes are committed in another state 70

States apply universal jurisdiction in different ways. Some regard international law as a part of their domestic rules automatically without needing to enact a specific law. Accordingly, when international law criminalises any act, these states could prosecute those committing international crimes even if these crimes were committed in other states and against other people ${ }^{71}$

In relation to crimes that fall under universal jurisdiction, the Institute of International Law stated in the Resolution of its $17^{\text {th }}$ Commission in 2005 that universal jurisdiction can be exercised over any "international crime identified by international law as falling within that jurisdiction in matters such as genocide, crimes against humanity, grave breaches of the 1949 Geneva Conventions for the protection of war victims or other serious violations of international humanitarian law committed in international or non-international armed conflict" 72

The resort to universal jurisdiction requires "the presence of the alleged offender in the territory of the prosecuting state or on board a vessel flying its

682006 Convention for the Protection of All Persons from Enforced Disappearance, UN Doc. A/Res/61/177, Annex, Art. 9 (2).

691984 Convention against Torture and Other Cruel, Inhuman or Degrading Treatment or Punishment, 1465 UNTS 112, Art. 5.

70 Questions relating to the Obligation to Prosecute or Extradite (Belgium v Senegal), Judgement, ICJ reports 2012, p. 1, at 31, para 91.

71 Amnesty International, 'Universal Jurisdiction: A Preliminary Survey of Legislation around the World', (2011) <http://www.amnesty.org/en/library/asset/IOR53/004/2011/en/d9973 66e-65bf-4d80-9022-fcb8fe284c9d/ior530042011en.pdf > at 9 [last accessed 2 December 2012]

72 Resolution of the Institute of International Law, Krakow Session, $17^{\text {th }}$ Commission, 'Universal Criminal Jurisdiction with regard to the Crime of Genocide, Crime against Humanity and War Crimes' (2005), Art 3(a) <http://www.idi-iil.org/idiE/resoluti onsE/2005_kra_03_en.pdf> [last accessed 16 March 2012] 
flag or an aircraft which is registered under its laws, or other lawful forms of control over the alleged offender.'73

The principle of universal jurisdiction allows individuals to bring a case against those who injured them. There are many examples of cases brought by individuals before the domestic courts of European countries that apply universal jurisdiction. In this context, since universal jurisdiction is exercised in criminal cases only, injured individuals should invoke criminal rather than civil jurisdiction; however, the court may compensate the victims with damages for violations of international law. Even foreign individuals can seek remedies against those committing international crimes. The Spanish judicial law for instance, allows victims of any nationality to file criminal proceedings against persons of any nationality committing serious crimes such as genocide, terrorism and other crimes under international treaties ratified by Spain ${ }^{74}$ This is still possible despite the recent amendments in the Spanish law in 2009 requiring a link between Spain and the case or the presence of the accused on Spanish territory 5 The UK position has also recently changed when Parliament passed the Police Reform and Social Responsibility Act 2011. The act requires the judge to obtain the consent of the Director of Public Prosecutions before hearing criminal complaints filed by private parties ${ }^{76}$ While this does not restrict the individual's right to initiate proceedings, it restricts the exercise of universal jurisdiction by British courts.

As regards the exercise of universal jurisdiction against states, criminal responsibility cannot be ascribed to states as they are just fictional entities that enjoy immunity; but the representatives of states can be held criminally responsible. It has been argued that immunity applies to heads of states and senior public officials.77 In this regard, the responsibility of official

73 Ibid., Art 3(b).

74 N. Roht-Arriaza, 'The Pinochet Precedent and Universal Jurisdiction', (2001) 35(2) New England Law Review 311.

75 M. Langer, 'The Diplomacy of Universal Jurisdiction: The Political Branches and the Transnational Prosecution of International Crimes', (2011) 105 AJIL 1, at 40.

76 Police Reform and Social Responsibility Act $2011<\mathrm{http}$ //www.legislation.gov.uk/ukpg a/2011/13/section/1/enacted $>$ [last accessed 19 March 2012]. The main reason behind this amendment was the complaint about the arrest warrant against the Israeli leaders accused of alleged war crimes. These criminal measures forced former Israeli Foreign Minister, Tzipi Livni, to cancel her trip to London in 2009 after an arrest warrant was issued against her. See British Israeli Communications and Research Center (1 April 2011) <http://www.bicom.org.uk/news-article/universal-jurisdiction-amendmentspass-commons-stages/> [last accessed 19 March 2012]

77 K. Roth, 'The Case For Universal Jurisdiction', (2001) <http://www.foreignaffairs.com/artic 
representatives of states may be blocked by immunity. However, the practice of some states proves that immunity cannot always be an obstacle in the way of exercising universal jurisdiction. For example, the House of Lords did not accept the plea of immunity by General Augusto Pinochet-military ruler of Chile from 1973 to 1990-when he was arrested in London in 1998 according to an arrest warrant issued against him in Spain 78 The House of Lords also decided that there is no immunity in relation to international crimes such as torture and immunity is just for the normal function of the officials of states. Furthermore, according to this decision, "since Chile, Spain and the United Kingdom had all ratified the Convention [Convention against Torture and other Cruel, Inhuman or Degrading Treatment or Punishment 1984] by 8 December 1988 the applicant could have no immunity for crimes of torture or conspiracy to torture after that date" 79

This decision raises a question relating to immunity of current officials of states who are accused of committing international crimes. It is proposed that there should be no distinction in this regard since the international treaties that the House of Lords relied on in its decision do not draw such a distinction. Furthermore, Pre-Trial Chamber I of the ICC issued two arrest warrants in 2009 and 2010 against Omar Al Bashir, the president of the Republic of Sudan, while he was still in power for allegedly committing crimes against humanity, war crimes and genocide ${ }^{80}$ Article 27 (1) of Rome Statute states that:

This Statute shall apply equally to all persons without any distinction based on official capacity. In particular, official capacity as a Head of State or Government, a member of a Government or parliament, an elected representative or a government official shall in no case exempt a person from criminal responsibility under this Statute, nor shall it, in and of itself, constitute a ground for reduction of sentence.

However, the ICJ in the Congo v Belgium case stated that although international courts such as the ICC and the International Criminal Tribunal for the former

les/57245/kenneth-roth/the-case-for-universal-jurisdiction> [last accessed 3 August 2012] See also G. Robertson, 'Ending Impunity: How International Criminal Law can Put Tyrants on Trial' (2005) 38 Cornell Int'1 L. J. 649.

78 Roht-Arriaza, supra note 74, at 312.

79 Regina v Bow Street Metropolitan Stipendiary Magistrate and others, ex parte Pinochet Ugarte (no. 3), House of Lords, [2000] 1 A.C. 147, at 148.

80 The Prosecutor v Omar Hassan Ahmad Al Bashir, International Criminal Court, ICC-02/05 -01/09 <http://www.icc-cpi.int> [last accessed 21 March 2012]. 
Yugoslavia (ICTY) can issue arrest warrants against serving state officials, national courts cannot, even if they have the requisite jurisdiction to do so in other circumstances. The court concluded that the provisions found in the charters and statutes of the permanent and temporary international courts (such as the ICC, Nuremberg and Tokyo Tribunals and the ICTY) allowing the prosecution of serving state officials, do not amount to a departure from the customary international rule which provides them with immunity from foreign criminal jurisdiction 81

It is perplexing for the ICJ to allow international courts to prosecute serving officials who enjoy immunity, while continuing to hold that customary international law does not allow national courts of other states with the requisite jurisdiction to do the same. The court also held that while current state officials may enjoy immunity against the jurisdiction of other states' domestic courts they may be tried:

1. before the national courts of their own states;

2. before other domestic courts if their national state waves their immunity;

3. before international courts or

4. by any domestic court with a jurisdiction over such acts after the official leaves their official post, as immunity will then cease to operate ${ }^{82}$

\subsubsection{The International Criminal Court}

According to Article 13 of the ICC Statute, the parties who have the right to file a case relating to alleged crimes under the jurisdiction of the court are a state party, the SC and the Prosecutor.

It is clear that there is no explicit indication of the right of individual victims to file a case before the court. However, this jurisdiction may be invoked through direct communication with the ICC Prosecutor. Article 13(c) gives the Prosecutor the authority to initiate an investigation proprio motu relating to crimes under the jurisdiction of the court. For this purpose the Prosecutor may gain information relating to these crimes from "states, organs of the United Nations, intergovernmental organisations, or reliable sources

\footnotetext{
81 Arrest Warrant of 11 April 2000 (Democratic Republic of the Congo v Belgium), Judgment, ICJ Reports 2002, p. 3, at 24, para 58.

${ }^{82}$ Ibid., at 25-6, para 61.
} 
that he or she deems appropriate" 83 It is estimated that the Office of the Prosecutor has received over 8733 communications since 2002 from more than 140 countries. The responsibility of the Prosecutor in these cases is to analyse a communication and determine whether there are reasonable grounds to proceed. Where the Prosecutor decides to initiate an investigation, the sender will be informed ${ }^{84}$ If the Prosecutor decides to initiate a criminal case, the victim could become a witness ${ }^{85}$

The foregoing can be applied to referrals to the ICC by states and the SC, which should be supported by information gathered from victims ${ }^{86}$

Additionally, the Rome Statute recognises the right of victims to reparation. It is submitted that this right of the individual as a victim to access the ICC can be invoked in civil litigation to request compensation directly. Article 75 (1) stipulates that the court has the mandate to:

establish principles relating to, or in respect of, victims, including restitution, compensation and rehabilitation. On the basis, in its decision the Court may, either upon request or on its own motion in exceptional circumstances, determine the scope and extent of any damage, loss and injury to, or in respect of, victims and will state the principles on which it is acting.

This means that although the jurisdiction of the ICC is specialised in criminal cases, the Statute still gives it the authority upon request to determine the scope and extent of any damage ${ }^{87}$ The reparation could be requested by victims and this should be interpreted as a way of allowing individuals access to the ICC even in civil matters.

The court may direct that reparation be paid by the convicted person or from the Trust Fund for Victims instituted by the Assembly of States Parties in $2002{ }^{88}$ To help victims in their participation before the ICC, the court

83 Rome Statute, supra note 53, Art.15.

84 ICC, 'Communications and Referrals', available at <http://www.icc-cpi.int/Menus/ICC/Situ ations+and+Cases/Referals+and+communications/> [last accessed 22 March 2012]

85 D. L. Shelton and T. Ingadottir, 'The International Criminal Court Reparations to Victims of Crimes (Art. 75 of the Rome Statute) and the Trust Fund (Art. 79)', Centre on International Cooperation, New York University <http://www.pict-pcti.org/publications/PICT_articl es/REPARATIONS.PDF> [last accessed 23 March 2012]

86 E. Baumgartner, 'Aspects of victim participation in the proceedings of the International Criminal Court' (2008) 90 IRRC 409, at 426.

87 See Shelton and Ingadottir, supra note 85.

88 Rome Statute, supra note 53, Art. 79. 
established the Office of Public Counsel for Victims in 2005 to support and assist them and their representatives to gain suitable reparation 89

The right of victims to apply for reparation is based on criminal proceedings. It is important to issue a decision from the ICC convicting the accused for committing the alleged crimes causing damage to the victims. 90

Nevertheless, despite the lack of explicit indication in the Statute that individuals can take their criminal claims to the ICC directly, they can still refer their cases by direct communication to the Prosecutor ${ }^{19}$ In this vein, Professor Schabas argues that "[i]ndividuals can make a complaint pursuant to article 15. The rights of victims under article 75 arise only as a consequence of the Prosecutor determining that he or she will proceed with an investigation"92

War crimes and crimes against humanity allegedly committed in Libya fall under the jurisdiction of the ICC pursuant to SC resolution 1970. Consequently, the ICC Chief Prosecutor has already committed the court to investigate all crimes (under its jurisdiction) in the Libyan war and issued some warrants of arrest. Thus all war crimes and crimes against humanity allegedly committed by Libyan forces loyal to Ghadafi fall under the jurisdiction of the court. It is, however, submitted that the crimes committed by NATO and other states' forces during the Libyan war also fall under the jurisdiction of the ICC, since the SC sought referral to investigate all crimes and was not restricted to those committed by forces loyal to the previous government. Thus, while discussing the progress in investigating alleged crimes in Libya, the ICC Prosecutor stated before the Security Council that:

There had also been allegations of crimes committed by the North Atlantic Treaty Organization (NATO) and the National Transitional Council-related forces, including the alleged detention of civilians suspected to be mercenaries and the alleged killing of detained combatants. Those allegations would be examined impartially and independently by the Office. Carrying out the investigations of all allegations would depend on the available budget ${ }^{93}$

\footnotetext{
${ }^{89}$ Report of the International Criminal Court to the General Assembly of the United Nations, 2006, UN Doc, A/61/217. See also, C. Evans, 'Reparations for Victims in International Criminal Law' in On-line Festschrift in honour of Katarina Tomasevski <http://rwi.lu.se/wpcontent/uploads/2012/04/Reparations-for-Victims-Evans.pdf> [last accessed 15 November 2012].

90 Evans, ibid.

91 Rome Statute, supra note 53, Art. 15.

92 Email from William Schabas to authors (04 April 2012)

93 'International Criminal Court Prosecutor Briefs Security Council on "Libya Case”, SC
} 
Although the ICC can render a case inadmissible as mentioned in Article 17 of the ICC Statute, the exceptions therein are applicable to the Libyan scenario. It is also important to appreciate that Libyans and nationals of states parties to the ICC statute have not been excluded from the jurisdiction of the ICC according to paragraph 6 of the 1970 SC resolution.

\section{Conclusion}

As the possibility of using diplomatic protection by the current regime to seek justice for injured Libyans is remote, the injured are entitled to seek other options. Thus, an individual could refer a case through communication to the ICC, which has exercised jurisdiction over Libya since 15 February 2011 according to SC resolution 1970. However, the SC has granted immunity from jurisdiction (with the exception of national jurisdiction) to all alleged wrongdoers from states that are non-parties to the ICC Statute. In this case, individual victims can resort to the domestic courts of the state of nationality of the alleged wrongdoers. Where those states do not apply this principle, this category can still be tried in national courts according to paragraph 6 of SC resolution 1970. As for all other alleged criminals in Libya, since Libyan courts are inoperative for the time being ${ }^{94}$ the ICC has jurisdiction over them. Libyan victims can initiate criminal cases by communicating with the ICC Prosecutor's office directly. Alternatively, Libyan victims can bring civil cases against NATO in Belgium as its headquarters is based there. They can also bring civil cases against a wrongdoing state (which participated in the war in Libya) in that state's own national courts. As for the criminal cases, if the official of NATO or a state who is accused of a crime is present in a territory of a state that applies the principle of universal jurisdiction, then the victims can bring a criminal claim before the domestic courts of that state. In some cases where the crime is of a nature (such as torture) which involves an international treaty that requires all states parties to prosecute or extradite the perpetrators present on their territory, a case can be brought before the courts in the state in which the alleged criminal is residing.

6647th Meeting (PM), SC/10433, 2 November 2011.

${ }^{94}$ See note 58 and accompanying text, supra. 